\title{
Executive Influence, Poverty Experience and Corporate Social Responsibility-Based on Empirical Evidence of Chinese A - Share Listed Companies
}

\author{
Bo Wang ${ }^{1}$, Huaming Wang ${ }^{2}$ \\ ${ }^{1}$ School of Civil Engineering and Architecture, Southwest University of Science and Technology, Mianyang, P. R. China \\ ${ }^{2}$ Planning Finance Division, Southwest University of Science and Technology, Mianyang, P. R. China
}

Email address:

boy5240@163.com (Bo Wang),393831787@qq.com (Huaming Wang)

\section{To cite this article:}

Bo Wang, Huaming Wang. Executive Influence, Poverty Experience and Corporate Social Responsibility—Based on Empirical Evidence of Chinese A - Share Listed Companies. International Journal of Business and Economics Research. Vol. 7, No. 3, 2018, pp. 62-70. doi: 10.11648/j.ijber.20180703.13

Received: June 12, 2018; Accepted: July 12, 2018; Published: July 19, 2018

\begin{abstract}
Taking 2012-2015 Chinese A-Share listed companies as the research object, this paper studies the impact of executive influence and poverty experience on the performance of corporate social responsibility. The results show that: executive influence is positively correlated with performance of corporate social responsibility, the higher the executive influence, the better corporate social responsibility is; compared with non-state-owned enterprises, executive influence has more influence on the performance of social responsibility of state-owned enterprises. poverty experience is positively correlated with performance of corporate social responsibility, the higher the poverty experience, the better corporate social responsibility is. Further research found that: executive poverty experience helps to strengthen the positive correlation between executive influence and corporate social responsibility, we should pay attention to the role of executive influence, at the same time cannot be ignored the effect of executive poverty on promoting the performance of corporate social responsibility.
\end{abstract}

Keywords: Executive Influence, Poverty Experience, Corporate Social Responsibility

\section{Introduction}

Why are there different levels of corporate social responsibility? Existing studies have given explanations from two perspectives: the company's external environment and internal characteristics. In the study of external factors, scholars focused on media reports [1], legal environment [2], and marketization [3]. In the research of internal governance factors, scholars mainly from the company performance [4], the board of directors decision [5], company characteristics (Porter and Kramer, 2006; Yang Junjie and Cao Guohua, 2016 discussed Several factors the impact on corporate social responsibility [6] [7]. Judging from existing researches, related research mainly focuses on the external environment and internal governance of the company and discusses the motives for the fulfillment of corporate social responsibility [8], while ignoring the factors and impacts of the "human" as a way to promote corporate social responsibility.

Executives, as spokespersons for corporate image, are the most influential policy leaders in the company [9] [10]. From existing studies, as the two different stages of executive life experience, executives' influence and early life experience can affect the executive's personality and behavior, and then affect corporate policy, operating performance and interest relations. improve. On the one hand, the influence of executives formed by various reputations and prestige at the peak of professionalism represents the personal image of senior executives and the society's expectations and recognition of companies, forming an important part of the company's core competitiveness, and Policy development and production and management have important influences [11] [12]. On the other hand, from the perspective of psychology, executives' early life experiences can affect senior executives' early psychology and values. In particular, poverty experiences have a greater impact on senior executives' early thoughts, and they can have a higher level of professional ethics and compassion for senior executives in the future. The training has played an important role [13]. Then, will the influence of 
senior executives and early poverty experience at the peak of their careers affect corporate social responsibility? What is the relationship between the two's influence mechanism and impact? The answers to these questions are conducive to further revealing the internal causes of the fulfillment of corporate social responsibility and clarifying the internal mechanism of executives' influence on the fulfillment of corporate social responsibility.

\section{Theoretical Analysis and Research Hypothesis}

\subsection{Executive Influence and Corporate Social Responsibility}

Why do companies have to fulfill social responsibilities? The agency theory believes that companies lack the motivation to fulfill their social responsibilities. Senior executives actively fulfill their social responsibilities and do not meet the principal's principle of maximizing profits. There have been studies that attributed the company's social responsibility to its own economic development, institutional arrangements [15], ethics, and external pressure [6]. As senior executives are the main decision makers and implementers of corporate policies, the influence of executive influence in promoting corporate social responsibility cannot be ignored. It has been considered that the establishment and maintenance of executive influence is a cyclical game process. The formation and accumulation of executive influence is the result of long-term game between senior management and stakeholders. Ponzi et al. (2011) analyzed the CEO's strategy for dealing with complex corporate affairs. He found that CEOs with greater influence had a better understanding of the game behavior among the stakeholders and achieved the best of the company's development by fulfilling their social responsibilities. Strategy. From the analysis of incentive theory, when executives have obtained a stable social status and have gained respect from the society, they can only realize the ideals and aspirations of life by maximizing the level of incentives, maximize their potential, and achieve self-worth. Maslow's hierarchy of needs theory can also explain this view. When executives meet their physical, security, emotional, and respect needs through their own efforts, they tend to maximize their personal value and make themselves better. The more people become socially desirable people, fulfill social responsibilities and assume social obligations are often the best way for executives to meet self-fulfillment needs [17]. Therefore, the greater the influence of senior executives, the more motivated and the desire to achieve their own values of life by fulfilling their social responsibilities. Based on this, this paper proposes Hypothesis 1:

H1: The greater the influence of senior executives, the higher the level of corporate social responsibility performance.

China is a country with economies in transition. State-owned and non-state-owned enterprises have large differences in their business goals and resource allocations. This has also resulted in very different styles and characteristics of the executives of state-owned and non-state-owned enterprises [7]. State-owned enterprises are guided by the multiple goals of economy, politics, and society. When executives of state-owned enterprises make decisions, they must consider not only business performance, but also more political and social goals. For example, they must call the country and meet environmental protection standards. Social responsibility requirements such as charity and social employment. Therefore, the executives of state-owned enterprises are faced with multiple pressures of corporate identity, government approval, and social identification. The higher the influence of senior executives of state-owned enterprises, the higher their expectations from all sectors of society are. Through active fulfillment of social responsibilities, they can meet the needs of enterprises. Performance requirements can achieve the expectations of all sectors of society, and at the same time, they can also increase their political careers and gain more chips. Compared with state-owned enterprises, non-state-owned enterprises can enjoy less social resources in the process of economic development, and in the market competition. With less room for benefits, executives need to consider fewer factors in decision-making, face lower reputational risks, and have relatively low enthusiasm and initiative to perform social responsibilities. Therefore, this paper proposes Hypothesis 2:

$\mathrm{H} 2$ : Compared with non-state-owned enterprises, the influence of senior executives has a stronger influence on the performance of state-owned enterprises in fulfilling their social responsibilities.

\subsection{Executive Poverty Experience and Corporate Social Responsibility Fulfillment}

The root causes of poverty are lack of material living conditions and lack of access to spiritual life. With regard to the impact of poverty on individuals, Elder et al. (1991) found that early experiences of individuals, especially poverty, can directly influence the behavior of individuals through the influence of thinking methods and value judgments. Hulme and Shepherd (2003) understood the poverty experience as the poverty environment and the atmosphere of the regional poverty. The poverty experience can affect the individual through the common value judgment criteria and practice memory of the environment. Malmendier et al. (2011) studied that poverty has a greater impact on individuals' mental and behavioral impacts. Poverty experiences as individuals' early experiences have a greater impact on individual growth. Executives are the main decision makers of companies, and the management style and value evaluation of senior executives are highly influenced by the personality characteristics of senior executives. Compared with the characteristics of senior management such as age, gender, and educational background, executives' poverty experiences have a bearing on the personalities of senior executives. The impact of features is more persistent. The poverty experience of senior executives can often bring more memory shocks to senior executives and further understand the importance of fulfilling their social responsibilities. Moon and Shen (2010) study found that executives who have experienced poverty are often more likely 
to resonate with people who have experienced the same experience, and put themselves in a position to think of others and try their best to express their feelings of concern and support. Therefore, executives with poverty experience often have a deeper understanding of poverty environment, difficult experience and disaster impact. When senior executives have the right to make decisions and have sufficient resources to control, they are more willing to undertake social obligations and fulfill their social responsibilities. Based on this, this paper proposes Hypothesis 3:

H3: Executives with poverty experience, the higher the corporate social responsibility performance level.

\subsection{Interaction Between Executive Influence and Poverty Experience}

Executives' influence and poverty experience are at two different stages in the life experience of executives. As an early life experience that influences the formation of the personality of senior executives, the poverty experience may have an enhanced effect on the influence of senior executives' influence on corporate social responsibility performance. The reasons are as follows: On the one hand, the greater the influence of senior executives, the more executives with poverty experience will cherish the hard-won external trust and prestige, and are more willing to strengthen their personal influence through active fulfillment of social responsibilities. On the other hand, from the perspective of psychology, the greater the influence of senior executives, the more social responsibility needs of the companies they face, and the executives with poverty experiences, their inner moral emotions are more likely to be touched, and the senior management's poverty experience will make The motivation of enterprises to fulfill their social responsibilities has shifted from economic incentives or institutional arrangements to the emotional and emotional experience of executives. Therefore, based on the above analysis, this paper proposes Hypothesis 4:

H4: The poverty experience has strengthened the positive relationship between executive influence and corporate social responsibility performance.

\section{Sample Selection and Research Design}

\subsection{Sample Selection and Data Sources}

This article takes the sample of A-share listed companies in China for the period from 2012 to 2015 as the sample. Based on this, the following samples are selected: (1) Financial and insurance companies are excluded; (2) ST and *ST companies are excluded; (3) Control variables have missing values and a sample of related financial data anomalies. Finally, a total of 1796 observations were obtained.

There are three main sources of data for this article: (1) Corporate Social Responsibility Performance Indicators are from Runling Global Corporate Social Responsibility (CSR) Rating System; (2) Executive Impact Data are from CCTV, First Financial Website, Sina Finance, Wealth Chinese website, Forbes Chinese website, Baidu Encyclopedia and related corporate official website, etc., all the basic data involved in the manual collection; (3) The data on the poverty situation of senior executives comes from the official website of the relevant company, the website of the State Council Office for Poverty Alleviation, Baidu Encyclopedia, celebrity interviews. The basic data involved in the programs, etc., were all collected manually; (4) The listed company's related financial data came from CSMAR database, WIND database and Sina Finance website. The statistical software used in this article is SPSS 22.0.

\subsection{Definition of Variables}

1. Corporate Social Responsibility (CSR). This article takes the 2012-2015 Runling Global Corporate Social Responsibility (CSR) rating as a proxy to measure the level of corporate social responsibility performance of listed companies. The evaluation data of Rouling Global Responsibility Rating Company's social responsibility performance for listed companies comes from the annual reports and social responsibility reports issued by related companies. The evaluation system indexes have strong objectivity, large amount of information, and high accuracy, and are used by more scholars. To measure the level of performance of social responsibility of listed companies. The higher the total score of CSR rating, the higher the level of social responsibility performance of listed companies.

2. Executive influence (INF). Using the practices of Mibourn (2003), this article defines senior executives as "CEO," "president," or "general manager." For the measurement method of executive influence, this paper draws on existing studies and considers that the influence of senior executives is influenced by many factors. The definition of executive influence is defined by social influence, industry influence, corporate influence, and government relations. Constituted by factors. The social influence is obtained by using provincial or above awards as an alternative indicator. Each time the senior executives get a provincial or higher award, the value of the assignment is 3 points; the industry influence is used by the senior executives to be selected by the media at the provincial or city level and the financial website. The list is used as a substitute indicator. In the term of office, each celebrity in the selected industry is ranked once, with an assigned value of 2 points. The influence of the company is replaced by the identity of the company's shareholders and employees. If the company is re-elected within the term, it means that the senior management has obtained the shareholder and Employees agree with an assignment of 1 point; government relations are used as substitute indicators for the senior executives during their tenure of office as members of deputies to the National People's Congress, members of the Chinese People's Political Consultative Conference, or whether they have government work experience. They will be assigned one-point assignment if they have delegates from major nationalities, members of the Chinese People's Political Consultative Conference or government work experience. Finally, the total score of the four indicators is calculated as a proxy for the influence of 
senior executives. The higher the total score of the indicator, the greater the influence of the executives. The composition of

executives' subdivision indicators is shown in Table 1.

Table 1. Composition of executive influence indicators.

\begin{tabular}{lllll}
\hline Index & social influence & Industry influence & Corporate influence & Government Relations \\
\hline maximum & 6 & 7 & 1 & 1 \\
Min & 0 & 0 & 0 & 0 \\
Total times & 946 & 898 & 463 & 279 \\
Sample size & 1796 & 1796 & 1796 & 1796 \\
\hline
\end{tabular}

Sources of data: CCTV, Forbes Chinese, CBN, Sina Finance, Fortune Chinese, Baidu Encyclopedia.

3. Poverty experience (POV). There are few studies on the measurement of poverty experiences in the existing literature. This paper refers to the measurement methods of Xu Nianxing and Li Zhe (2016) and improves them. The following three indicators are selected to constitute the surrogate indicators of the poverty experience of top managers: (1) The formation of the personality of senior executives in the early years relied on the development environment of their hometowns. The common economic activities, collective memory, and spiritual characteristics of the region have important implications for the formation of the early personality of senior executives. Therefore, Considering the poor environment of senior executives in the early years, they were selected as the "national poor counties" recognized by the State Council's Office of Poverty Alleviation in 2012 as a surrogate indicator. The comparison was made between the senior management's birthplace and the list of impoverished counties, and the "national impoverished counties" were assigned a value of 1
(2) Referring to the measurement method of Xu Nianxing and $\mathrm{Li}$ Zhe (2016), consider whether senior executives experienced the "three-year hardship period"(1959-1961) as an alternative indicator in the early years. According to the division of age in childhood for the age of childhood, the upper limit of the age of childhood is defined as 14 years old, therefore, the executives who were born from 1947 to 1961 are assigned a value of 1 . Otherwise, the assignment is 0 ; (3) sudden natural disasters (earthquakes), family tragedies and serious diseases will bring pain and suffering to the early years of executive experience, and thus lead to family poverty. As a result, executives experience 1 point of sudden disaster in their childhood, otherwise they are assigned 0 points. The sum of the scores of the above three indicators will form a surrogate indicator of the early poverty management experience of senior executives. The larger the index value, the more experienced the poverty of senior managers. Table 2 shows the statistical data of senior management poverty.

Table 2. Statistics on Poverty Experience of Executives.

\begin{tabular}{llll}
\hline Index & National poverty counties & Three years of hard times & Sudden disaster \\
\hline Number of people & 131 & 659 & 47 \\
Sample size & 1796 & 1796 & 1796 \\
proportion & $7.29 \%$ & $36.70 \%$ & $2.62 \%$ \\
\hline
\end{tabular}

Sources of data: official website of relevant companies, website of State Council Office for Poverty Alleviation, Baidu Encyclopedia, biography of celebrities, and interviews.

4. Control Variables. Taking into account the relevant factors that may have an impact on corporate social responsibility, this article draws on the relevant research practices of Brammer and Pavelin (2004), Cui Xiumei (2009), and Shen Hongtao (2010) to select company size (SIZE), Profitability (EPS), Financial Leverage (LEV), Nature of Property (STATE) and Age of
Listing (LISTGE) are the control variables for this study. In addition, annual dummy variables (YEAR) and industry dummy variables (INDUSTRY) were added to control annual and industry fixed effects.

The detailed definition of variables in this paper is shown in Table 3.

Table 3. Variable Definitions and Measurements.

\begin{tabular}{lll}
\hline Variable symbol & Variable name & Variable metrics \\
\hline CSR & Corporate social responsibility & Using Runling Global Corporate Social Responsibility to perform a total score \\
A weighted total score for provincial and above awards, selected industry celebrity lists, \\
INF & Executive influence & Sum of National Poverty Counties, Three-year Hard Times, and Sudden Disaster Scores \\
POV & Poverty experience & Natural logarithm of total assets \\
SIZE & Company Size & Net profit/total equity \\
EPS & Profitability & total liabilities / total assets \\
LEV & Financial Leverage & State-owned property companies have a value of 1 , otherwise they are assigned a value of 0. \\
STATE & Nature of property & Years listed \\
LISTGE & Age of listing & virtual variable \\
YEAR & years & virtual variable \\
INDUSTRY & industry &
\end{tabular}




\subsection{Inspection Model}

This paper builds the following model, in which model (1) tests whether executive influence influences corporate social responsibility fulfillment to verify hypotheses 1 and 2; model (2) is used to test the impact of poverty on corporate social responsibility performance. Assay Hypothesis 3; Model (3) is used to test the role of poverty experiences in regulating the influence of executives and corporate social responsibilities to validate hypotheses 4 presented in this paper.

$$
\begin{aligned}
& \text { CSR }=\beta_{0}+\beta_{1} \text { INF }+\beta_{2} \text { SIZE }+\beta_{3} \text { EPS }+\beta_{4} \text { LEV }+\beta_{5} \text { STATE } \\
& +\beta_{6} \text { LISTGE }+\beta_{7} \text { YEAR }+\beta_{8} \text { INDUSTRY }+\varepsilon \\
& \text { CSR }=\beta_{0}+\beta_{1} \text { POV }+\beta_{2} \text { SIZE }+\beta_{3} \text { EPS }+\beta_{4} \text { LEV }+\beta_{5} \text { STATE } \\
& +\beta_{6} \text { LISTGE }+\beta_{7} \text { YEAR }+\beta_{8} \text { INDUSTRY }+\varepsilon \\
& \text { CSR }=\beta_{0}+\beta_{1} \text { INF }+\beta_{2} \text { POV }+\beta_{3} \text { INF } * \text { POV }+\beta_{4} \text { SIZE }+\beta_{5} \text { EPS } \\
& +\beta_{6} \text { LEV }+\beta_{7} \text { STATE }+\beta_{8} \text { LISTGE }+\beta_{9} \text { YEAR }+\beta_{10} \text { INDUSTRY }+\varepsilon
\end{aligned}
$$

\section{Empirical Test and Analysis}

\subsection{Descriptive Statistics of Variables}

Table 4 shows the descriptive statistics of the main variables studied in this paper. From Table 4, it can be seen that the maximum value of the total social corporate performance score of selected sample companies is 87.95 , the minimum value is 15.12 , the median is 36.06 , and the standard deviation is 12.04 , reflecting that the overall level of corporate social responsibility performance of listed companies in China remains to be determined. The improvement in the level of fulfillment of different corporate social responsibilities is quite different, which is in line with the current overall status of corporate social responsibilities in China. According to the total score of senior executives' influence, the maximum value is 26 , the minimum value is 0 , the median value is 2.7 , and the average value is 3.4 , which reflects that the level of influence of senior executives of listed companies in China is very different, and also reflected from the side. High-impact senior executives are more concentrated, indicating that the managerial market under the conditions of China's market economy lacks vitality. From the point of view of poverty experience, the minimum value is 0 , the median is 0 , the $3 / 4$ digit is 1 , the mean is 0.44 , reflecting that the proportion of

\begin{tabular}{|c|c|c|c|c|c|c|c|c|}
\hline variable & Observations & Mean & Standard & Min & 1/4 digit & median & 3/4digit & Max \\
\hline CSR & 1796 & 39.17 & 12.04 & 15.12 & 31.00 & 36.06 & 44.35 & 87.95 \\
\hline INF & 1796 & 3.40 & 3.76 & 0.00 & 0.81 & 2.70 & 4.86 & 26.00 \\
\hline POV & 1796 & 0.44 & 0.58 & 0.00 & 0.00 & 0.00 & 1.00 & 3.00 \\
\hline SIZE & 1796 & 23.16 & 1.47 & 20.18 & 22.06 & 23.01 & 24.08 & 28.51 \\
\hline EPS & 1796 & 0.45 & 0.53 & -2.26 & 0.12 & 0.31 & 0.67 & 3.63 \\
\hline LEV & 1796 & 49.59 & 20.21 & 0.80 & 34.81 & 51.32 & 65.37 & 93.06 \\
\hline LISTGE & 1796 & 12.07 & 5.53 & 0.00 & 8.00 & 12.00 & 16.00 & 25.00 \\
\hline
\end{tabular}
senior executives in the selected sample with early poverty experience is not particularly high, but different There is a significant difference in the level of poverty experience among senior executives in enterprises.

Table 4. Variable descriptive statistics.

\subsection{Regression Analysis}

Table 5 shows the regression results for Hypothesis 1 and Hypothesis 2. From the regression result of (1), it can be found that the regression coefficient of executive influence (INFi, t-1) is 0.164 , and it is significant at the level of $1 \%$, indicating that executive influence and corporate social responsibility performance are significantly positive relationship. The greater the influence of senior executives, whether it is for economic reasons, institutional reasons, or self-realization needs, senior executives as the company's major policy makers and executives will actively promote the company to fulfill its social responsibilities and assume social obligations. From this, hypothesis 1 is verified. From the regression results of (2), it can be found that the coefficient of senior management influence (INFi, t-1) of state-owned enterprises is 0.168 , which is significantly positively correlated with the level of $1 \%$, and the influence of senior executives of non-state-owned enterprises is different. The coefficient of (INFi, t-1) is 0.124 , and there is a significant positive correlation at the $1 \%$ level. It can be seen from the comparison of the two groups of executive influence (INFi, t-1) coefficients that the state-owned company executive influence (INFi The coefficient of ( $t-1)$ is obviously greater than that of non-state-owned enterprises (INFi, $\mathrm{t}-1$ ), which shows that compared with non-state-owned enterprises, the executive influence of state-owned enterprises is more relevant to the fulfillment of corporate social responsibility. From this, 
Hypothesis 2 is verified.

Table 5. Sample regression analysis results.

\begin{tabular}{|c|c|c|c|c|c|c|}
\hline \multirow{4}{*}{ variable } & \multicolumn{6}{|l|}{$\mathrm{CSR}_{\mathrm{i}, \mathrm{t}}$} \\
\hline & \multirow{2}{*}{\multicolumn{2}{|c|}{$\begin{array}{l}\text { (1) } \\
\text { Full sample }\end{array}$}} & \multicolumn{4}{|l|}{ (2) } \\
\hline & & & \multicolumn{2}{|l|}{ State-owned } & \multicolumn{2}{|c|}{ Non-state owned } \\
\hline & coefficient & T value & coefficient & T value & coefficient & T value \\
\hline $\mathrm{C}$ & $-54.506^{* * *}$ & -11.785 & $-59.557^{* * *}$ & -8.973 & $-49.534^{* * *}$ & -6.680 \\
\hline $\mathrm{INF}_{\mathrm{i}, \mathrm{t}-1}$ & $0.164^{* * *}$ & 7.976 & $0.168^{* * *}$ & 5.564 & $0.124^{* * *}$ & 4.891 \\
\hline $\operatorname{SIZE}_{\mathrm{i},-1-1}$ & $0.519^{* * * *}$ & 19.002 & $0.516^{* * *}$ & 14.556 & $0.483^{* * *}$ & 11.432 \\
\hline $\mathrm{EPS}_{\mathrm{i}, \mathrm{t}-1}$ & 0.004 & 0.190 & 0.038 & 1.278 & -0.046 & -1.364 \\
\hline $\mathrm{LEV}_{\mathrm{i}, \mathrm{t}-1}$ & $-0.179^{* * *}$ & -7.047 & $-0.122^{* * *}$ & -3.645 & $-0.238^{* * *}$ & -5.838 \\
\hline $\mathrm{STATE}_{\mathrm{i},-1-1}$ & $0.079^{* * *}$ & 3.624 & & & & \\
\hline LISTGE $_{i, t-1}$ & $-0.088^{* * *}$ & -4.183 & -0.025 & -0.858 & $-0.145^{* * *}$ & -4.450 \\
\hline YEAR & control & & control & & control & \\
\hline INDUSTRY & control & & control & & control & \\
\hline F value & $116.095^{* * *}$ & & $78.858^{* * *}$ & & $36.932^{* * *}$ & \\
\hline Adj. $R^{2}$ & 0.278 & & 0.312 & & 0.161 & \\
\hline $\mathrm{N}$ & 1796 & & 860 & & 936 & \\
\hline
\end{tabular}

Note: *** indicates significant at $1 \%$ level; ** indicates significant at $5 \%$ level; * indicates significant at $10 \%$ level.

Table 6 shows sample regression results for Hypothesis 3 and Hypothesis 4. From the regression results of (3), it can be found that the regression coefficient of poverty experience (POVi, $\mathrm{t}-1$ ) is 0.123 , and it is significant at the level of $1 \%$. There is a significant positive correlation between executive poverty and corporate social responsibility performance. Executives with poverty experiences have more poverty experiences and higher levels of corporate social responsibility. Explain the early experiences of senior executives, especially their poverty experiences. What they saw and heard and the early feelings of poor living had a significant impact on the psychology of executives and the formation of values in the process of professional growth. When they became senior executives and had resources to control After the ability, understand more importantly the significance of social responsibility. The poverty experience and psychological speciality of senior executives make them more motivated to promote the company's active implementation of social responsibility. From this, hypothesis 3 is verified. By observing the regression results of (4), the coefficient of the interaction term (INFi, $\mathrm{t}-1 \times \mathrm{POVi}, \mathrm{t}-1$ ) between executive influence and poverty experience is 0.065 , and it is significant at the level of $10 \%$, during the interaction process, Executive influence (INFi, t-1) and poverty experience (POVi, $\mathrm{t}-1$ ) remained positively correlated with the fulfillment of corporate social responsibility, indicating that the poverty experience strengthened executive influence and corporate social responsibility The positive relationship of fulfillment. On the one hand, the greater the influence of senior executives, the more executives with poverty experience will cherish their own identity and hard-won reputation and corporate development results, more willing to maintain personal influence and corporate brand image through fulfillment of social responsibility. On the other hand, the greater the influence of senior executives, the greater the social expectation of the company, and the greater the pressure of corporate social responsibility from the outside, the more psychologically vulnerable the executives to fulfill their social responsibilities are more likely to be touched. From this, hypothesis 4 is verified.

Table 6. Sample regression analysis results.

\begin{tabular}{|c|c|c|c|c|}
\hline \multirow{3}{*}{ variable } & \multicolumn{4}{|l|}{$\operatorname{CSR}_{\mathrm{i}, \mathrm{t}}$} \\
\hline & \multicolumn{2}{|l|}{ (3) } & \multicolumn{2}{|l|}{ (4) } \\
\hline & coefficient & T value & coefficient & T value \\
\hline $\mathrm{C}$ & $-54.023^{* * *}$ & -11.494 & $-49.929^{* * *}$ & -10.683 \\
\hline $\mathrm{INF}_{\mathrm{i}, \mathrm{t}-1}$ & & & $0.124^{* * *}$ & 4.891 \\
\hline $\mathrm{POV}_{\mathrm{i}, \mathrm{t}-1}$ & $0.123^{* * *}$ & 5.909 & $0.062^{*}$ & 1.944 \\
\hline $\mathrm{INF}_{\mathrm{i}, \mathrm{t}-1} \times \mathrm{POV}_{\mathrm{i}, \mathrm{t}-1}$ & & & $0.065^{*}$ & 1.767 \\
\hline SIZE $_{i, t-1}$ & $0.524^{* * *}$ & 18.908 & $0.493^{* * *}$ & 17.850 \\
\hline $\mathrm{EPS}_{\mathrm{i}, \mathrm{t}-1}$ & 0.003 & 0.149 & 0.001 & 0.005 \\
\hline $\mathrm{LEV}_{\mathrm{i}, \mathrm{t}-1}$ & $-0.178^{* * *}$ & -6.995 & $-0.175^{* * *}$ & -6.947 \\
\hline STATE $_{\mathrm{i}, \mathrm{t}-1}$ & $0.066^{* * *}$ & 3.038 & $0.080^{* * *}$ & 3.684 \\
\hline LISTGE $_{\mathrm{i}, \mathrm{t}-1}$ & $-0.099^{* * *}$ & -4.702 & $-0.091^{* * *}$ & -4.348 \\
\hline YEAR & control & & control & \\
\hline INDUSTRY & control & & control & \\
\hline F value & $109.679^{* * *}$ & & $91.943^{* * *}$ & \\
\hline Adj. $R^{2}$ & 0.266 & & 0.288 & \\
\hline $\mathrm{N}$ & 1796 & & 1796 & \\
\hline
\end{tabular}

Note: $* * *$ indicates significant at $1 \%$ level; ** indicates significant at $5 \%$ level; * indicates significant at $10 \%$ level. 
From the regression results of the control variables selected in Table 5 and Table 6 , the scale of the company is significantly positively related to the fulfillment of corporate social responsibility, indicating that the larger the scale of the company, the higher the level of corporate social responsibility performance; the earnings per share and corporate social responsibility fulfillment Relevant, but not significant; financial leverage and corporate social responsibility performance significantly negative correlation, indicating that the higher the debt, the lower the level of corporate social responsibility to perform; listing age and corporate social responsibility performance is significantly negatively correlated, indicating that the shorter the time to market, the more the company Paying attention to the fulfillment of social responsibilities is related to the establishment of a brand image that has just been listed on companies. The regression results of other control variables are also basically consistent with the existing research results.

\subsection{Robustness Test}

(1) Replace the proxy variable of the explanatory variable. In order to test the robustness of the relationship between executives' influence and corporate social responsibility performance, this article draws on the measurement methods of Yang Junjie and Cao Guohua (2016) [7]. Using Baidu's news search function, select senior executives for the search period and enter the names of executives. Searching for company names, using the total number of news items as an alternative variable for senior executives, conduct regression verification. At the same time, in order to test the soundness of the relationship between the poverty experience and the fulfillment of corporate social responsibilities, the paper makes adjustments to the measurement of poverty experiences as follows: First, the research method of Xu Nianxing and Li Zhe (2016) will be adopted for poor counties. The scope of verification has been adjusted from the data of 2012 to the data of 1994. Second, after the reform and opening up, China officially went to the path of enriching the people and strengthening the country. This article will identify the period of poverty during the "three-year difficult period" as the reform and opening up, that is: Taking 1978 as a period of economic poverty, considering that the upper limit of childhood time is 14 years old, executives born in 1964-1978 are counted as having early poverty. The specific method of valuation remains unchanged. Finally, the total score of senior management poverty is calculated and verified by regression.

For example, Table 7 shows the results of the robustness test: As can be seen from the regression results, the regression result of executive influence (INFi, t-1) is 0.127 , and it is significant at the level of $1 \%$, indicating that after changing the measurement method, the executives The significant positive correlation between influence and corporate social responsibility performance remains unchanged. The regression coefficient of poverty experience (POVi, $\mathrm{t}-1$ ) is 0.129 , and it is significant at the level of $1 \%$, indicating that after the measurement is changed, the significant positive correlation between the poverty experience and corporate social responsibility performance remains unchanged.

Table 7. Robustness test results.

\begin{tabular}{|c|c|c|c|c|}
\hline \multirow{3}{*}{ variable } & \multicolumn{4}{|l|}{$\mathbf{C S R}_{\mathrm{i}, \mathrm{t}}$} \\
\hline & \multicolumn{2}{|c|}{ Change in executive influence measurement method } & \multicolumn{2}{|c|}{ Change in poverty measurement methods } \\
\hline & coefficient & T value & coefficient & T value \\
\hline $\mathrm{C}$ & $-54.407^{* * *}$ & -11.614 & $-54.439^{* * *}$ & -11.637 \\
\hline $\mathrm{INF}_{\mathrm{i}, \mathrm{t}-1}$ & $0.127^{* * *}$ & 6.044 & & \\
\hline $\mathrm{POV}_{\mathrm{i}, \mathrm{t}-1}$ & & & $0.129^{* * *}$ & 6.212 \\
\hline $\operatorname{SIZE}_{i, t-1}$ & $0.524^{* * *}$ & 18.949 & $0.526^{* * *}$ & 19.117 \\
\hline $\mathrm{LEV}_{\mathrm{i}, \mathrm{t}-1}$ & $-0.169^{* * *}$ & -6.604 & $-0.180^{* * *}$ & -7.028 \\
\hline STATE $_{\mathrm{i}, \mathrm{t}-1}$ & $0.078^{* * *}$ & 3.547 & $0.066^{* * *}$ & 2.999 \\
\hline LISTGE $_{\mathrm{i}, \mathrm{t}-1}$ & $-0.095^{* * *}$ & -4.484 & $-0.105^{* * *}$ & -4.991 \\
\hline YEAR & control & & control & \\
\hline INDUSTRY & control & & control & \\
\hline F value & $110.040^{* * *}$ & & $110.500^{* * *}$ & \\
\hline Adj. $R^{2}$ & 0.267 & & 0.268 & \\
\hline $\mathrm{N}$ & 1796 & & 1796 & \\
\hline
\end{tabular}

Note: $* * *$ indicates significant at $1 \%$ level; $* *$ indicates significant at $5 \%$ level; $*$ indicates significant at $10 \%$ level.

(2) Replace the agent variable of the interpreted variable. To examine the robustness of the CSR of the explanatory variable to the results of the study, this paper considers the close relationship between corporate charitable donations and corporate social responsibilities, and at the same time ensures the comparability of charitable donations among different companies. Finally, it uses charitable donations to account for the The proportion of total assets as a proxy for the fulfillment of corporate social responsibilities, through the regression test, the relevant research conclusions have not changed, limited space, no longer listed the robustness test empirical results, if necessary, contact the author.

\section{Conclusions and Inspiration}

This article takes the Chinese A-share listed companies 
from 2012 to 2015 as the research object, and studies the impact of senior executives' influence and poverty experience on the fulfillment of corporate social responsibilities. It also analyzes whether the poverty experience will enhance the influence of senior executives and the fulfillment of corporate social responsibilities. relationship. Through the study of this paper, it is found that: (1) There is a significant positive correlation between executive influence and corporate social responsibility performance. The greater the influence of senior executives, whether it is for economic reasons, institutional arrangements, or the need for self-worth, senior executives are motivated to push their companies to actively fulfill their social responsibilities and select other variables as an alternative variable for senior executives' influence. The inspections and research findings are consistent; (2) Compared with non-state-owned enterprises, the executive influence of state-owned enterprises is more relevant to the fulfillment of corporate social responsibility. Executives of state-owned enterprises are faced with multiple pressures from corporate identity, government approval, and social identification. The higher the influence of senior executives of state-owned enterprises, the higher their expectations from all walks of life. Through active fulfillment of social responsibilities, they can meet corporate performance requirements. It can also realize the expectations of all sectors of the society and at the same time, it can also gain more chips for the improvement of its political career. (3) There is a significant positive correlation between the poverty experience of senior executives and the fulfillment of corporate social responsibility. The more poverty experiences experienced by senior executives, the higher the level of fulfillment of social responsibility of their companies, indicating that the early impoverished economy of senior executives gave senior executives a greater memory impact, and also made executives more compassionate and more willing to be at the peak of their careers. Actively repay the society and assume responsibility; (4) The poverty experience of senior executives strengthens the positive correlation between executive influence and corporate social responsibility fulfillment. The greater the influence of senior executives, the higher the social expectation, and the social responsibilities of senior executives with poverty experiences are more likely to be touched, and the stronger the original motivation for actively fulfilling social responsibilities.

The conclusion of this paper has important theoretical and practical significance. (1) From the perspective of the life experiences of senior executives, the impact on corporate social responsibility research is still relatively rare in existing research literature. Senior executives are the main policy makers and implementers of enterprises, and senior executives can not neglect the role of corporate social responsibility fulfillment; (2) Based on the growth process of senior executives, influence from senior executives and the early stages of career growth of senior executives. Poverty experiences are taken into account, and the indicators of these two factors are quantified to empirically analyze the impact mechanism on corporate social responsibility performance.
The research in this paper provides new ideas and measurement methods for relevant research; (3) The influence of senior executives is the core of the company. As an important component of competitiveness, in the process of corporate management in the future, it is important to attach importance to the important role of executive influence in promoting the implementation of corporate social responsibility; (4) Poverty experience is also a fortune, whether at the corporate level or the government level. It is necessary to fully understand the positive impact of poverty on business management. At the same time, it must also educate and educate senior executives who have superior early living conditions, establish a sense of social responsibility, and undertake social responsibilities.

\section{References}

[1] Dyck A., Volchkova N., Zinglaes L. The Corporate Governance Role of The Media: Evidence from Russia [J]. Journal of Finance, 2008, 63 (3):1093-1136.

[2] Joe, J., H. Louis, and D. Robinson. Managers' and Investors' Responses to Media Exposure of Board Ineffectiveness [J]. Journal of Financial and Quantitative Analysis, 2009, 44 (3):579-605.

[3] Peng Yu, Chen Hongqiang. Internal Control, Marketization Process and Corporate Social Responsibility [J]. Modern Finance and Economics, 2015 (6): 43-51.

[4] Kuhnen C, Niessen A. Is Executive Compensation Shaped by Public Attitudes? [R]. Evanston:Northwestern University, 2009.

[5] Enikolopov, R., Petrova, M., Zhuravskaya, E. Media and Political Persuasion: Evidence from Russia [J]. American Economic Review, 2011, 101 (7): 3253-3285.

[6] Porter M E, Kramer M R. Strategy and Society: The Link between Competitive Advantage and Corporate Social Responsibility [J]. Harvard Business Review, 2006 (12): 36-37.

[7] Yang Junjie, Cao Guohua. CEO Reputation, Earnings Management and Investment Efficiency [J]. Soft Science, 2016, 30 (11):71-77.

[8] Jennifer, F., H. Allen, R. Shivaram. CEO Reputation and Earnings Quality [J]. Contemporary Accounting Research, 2008, 25 (1): 109-147.

[9] Graham, J., Harvey, and M. Puri. Capital Allocation and Delegation of Decision making Authority within Firms [J]. Journal of Financial Economics, 2015, (115) 449-470.

[10] Steven F. Cahan, Chen Chen, Nhut H. Nguyen. Corporte Social Responsibility and Media Coverage [J]. Journal of Banking and Finance, 2015 (59):19-27.

[11] Benson. What Determines Success? Examining The Human, Financial and Social Capital of Jamaican Microentrepreneurs [J]. Journal of Business Venturing, 1998 (13):371-394.

[12] Hui Zhengyi. Corporate Social Responsibility Top Management Influence [N]. China Business News, May 2008 (C05). 
[13] Hahn, A., and B. Gawronski. Implicit Social Cognition [J]. International Encyclopedia of the Social and Behavioral Sciences, 2015, (17):714-720.

[14] Brammer S J, Pavelin S. Building a Good Reputation [J]. European Management Journal, 2004 (12):704 -713.

[15] Zyglidopoulos, Georgiadis. Does Media Attention Drive Corporate Social Responsibility? [J]. Journal of Business Research, 2012, 65 (11):1622-1627.

[16] Ponzi L J, Fombrun C J, Gardberg N A. RepTrak Pulse:Conceptualizing and Validating a Short Form Measure of Corporate Reputation [J]. Corporate Reputation Review, 2011, 14 (1):15-35.

[17] Hofstede, G. The cultural relativity of the quality of life concept [J]. Academy of Management Review, 1984 (07): 389-398.
[18] Sen, Amartya. Social Exclusion, Critical Quest [M]. India: New Delhi, 2004.

[19] Elder, G., C. Gimbel. Turning Points in Life: The Case of Military Service and War [J]. Military Psychology, 1991 (3): 215-231.

[20] Hulme, D., and A. Shepherd. Conceptualizing Chronic Poverty [J]. World Development, 2003, 31 (3):403-423.

[21] Malmendier, U., Tate, and Yan. Overconfidence and Early life Experiences: The Effect of Managerial Traits on Corporate Financial Policies [J]. Journal of Finance, 2011 (66):1687-1733. 